December 1998 • NREL/CP-520-25631

\title{
New Materials for Future Generations of III-V Solar Cells
}

J.F. Geisz, D.J. Friedman, J.M. Olson, C. Kramer, A. Kibbler, and S.R. Kurtz

National Renewable Energy Laboratory

Presented at the National Center for Photovoltaics Program Review Meeting

Denver, Colorado

September 8-11, 1998

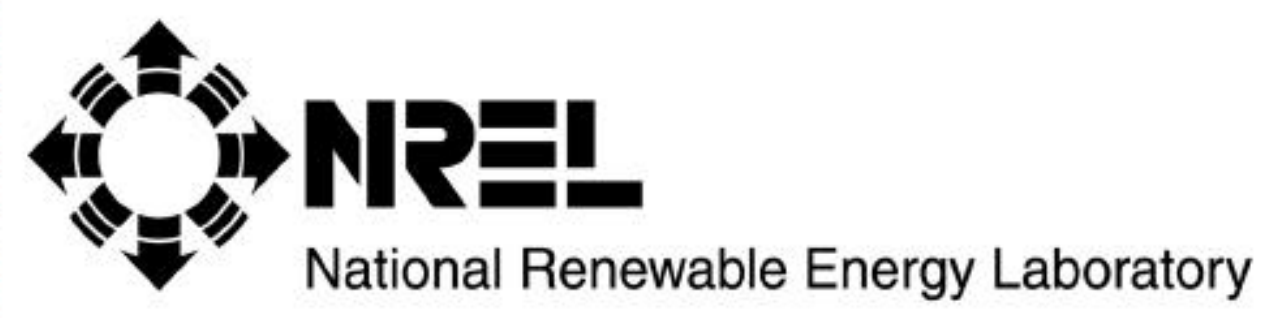

1617 Cole Boulevard

Golden, Colorado 80401-3393

NREL is a U.S. Department of Energy Laboratory

Operated by Midwest Research Institute $\cdot$ Battelle $\bullet$ Bechtel 


\section{NOTICE}

This report was prepared as an account of work sponsored by an agency of the United States government. Neither the United States government nor any agency thereof, nor any of their employees, makes any warranty, express or implied, or assumes any legal liability or responsibility for the accuracy, completeness, or usefulness of any information, apparatus, product, or process disclosed, or represents that its use would not infringe privately owned rights. Reference herein to any specific commercial product, process, or service by trade name, trademark, manufacturer, or otherwise does not necessarily constitute or imply its endorsement, recommendation, or favoring by the United States government or any agency thereof. The views and opinions of authors expressed herein do not necessarily state or reflect those of the United States government or any agency thereof.

Available to DOE and DOE contractors from:

Office of Scientific and Technical Information (OSTI)

P.O. Box 62

Oak Ridge, TN 37831

Prices available by calling 423-576-8401

Available to the public from:

National Technical Information Service (NTIS)

U.S. Department of Commerce

5285 Port Royal Road

Springfield, VA 22161

703-605-6000 or 800-553-6847

or

DOE Information Bridge

http://www.doe.gov/bridge/home.html 


\title{
New Materials for Future Generations of III-V Solar Cells
}

\author{
J.F. Geisz, D.J. Friedman, J.M. Olson, \\ C. Kramer, A. Kibbler, and Sarah R. Kurtz \\ National Renewable Energy Laboratory \\ 1617 Cole Blvd., Golden, CO 80401
}

\begin{abstract}
Three- and four-junction III-V devices are proposed for ultrahigh-efficiency solar cells using a new 1-eV material lattice-matched to GaAs, namely, GaInNAs. We demonstrate working prototypes of a GaInNAs-based solar cell lattice-matched to GaAs with photoresponse down to $1 \mathrm{eV}$. Under the AM1.5 direct spectrum with all the light higher in energy than the GaAs band gap filtered out, the prototypes grown with base doping of about $10^{17} \mathrm{~cm}^{-3}$ have open-circuit voltages ranging from 0.35 to $0.44 \mathrm{~V}$, short-circuit current densities of $1.8 \mathrm{~mA} / \mathrm{cm}^{2}$, and fill factors from $61 \%$ to $66 \%$. To improve on the current record-efficiency tandem GaInP/GaAs solar cell by adding a GaInNAs junction, the short-circuit current density of this $1-\mathrm{eV}$ cell must be significantly increased. Because these low short-circuit current densities are due to short diffusion lengths, we have demonstrated a depletion-width-enhanced variation of one of the prototype devices that trades off decreased voltage for increased photocurrent, with a short-circuit current density of $7.4 \mathrm{~mA} / \mathrm{cm}^{2}$ and an open-circuit voltage of $0.28 \mathrm{~V}$.
\end{abstract}

\section{INTRODUCTION}

The $\mathrm{Ga}_{0.5} \mathrm{In}_{0.5} \mathrm{P} / \mathrm{GaAs}$ tandem solar cell is in production for space photovoltaic applications and is a leading candidate for terrestrial high-concentration photovoltaics because of its record-setting efficiency $(1,2)$. The addition of an active Ge junction, yielding a three-junction device, has been demonstrated to boost efficiencies further. However, the Ge band gap is not optimal for the third junction: significantly higher efficiencies would be obtained if the third junction could be fabricated from a 1-eVband-gap material. If this next generation of multijunction devices could be achieved, the Ge junction could be reintroduced under this three-junction stack for a resulting monolithic, two-terminal device with projected real-world efficiencies above $35 \%$ for air-mass 0 (AM0) and above 40\% for 500-suns terrestrial (3). This evolution of multijunction solar-cell structures from the existing two-junction device to futuregeneration three- and four-junction devices is shown in Figure 1, with projected idealized efficiencies for these devices. (Practical efficiencies can be expected to be $\sim 80 \%$ of the idealized values.) The crucial step in the evolution to these next generations of ultrahigh-efficiency devices is to develop the 1-eV third cell latticematched to GaAs (or Ge). 


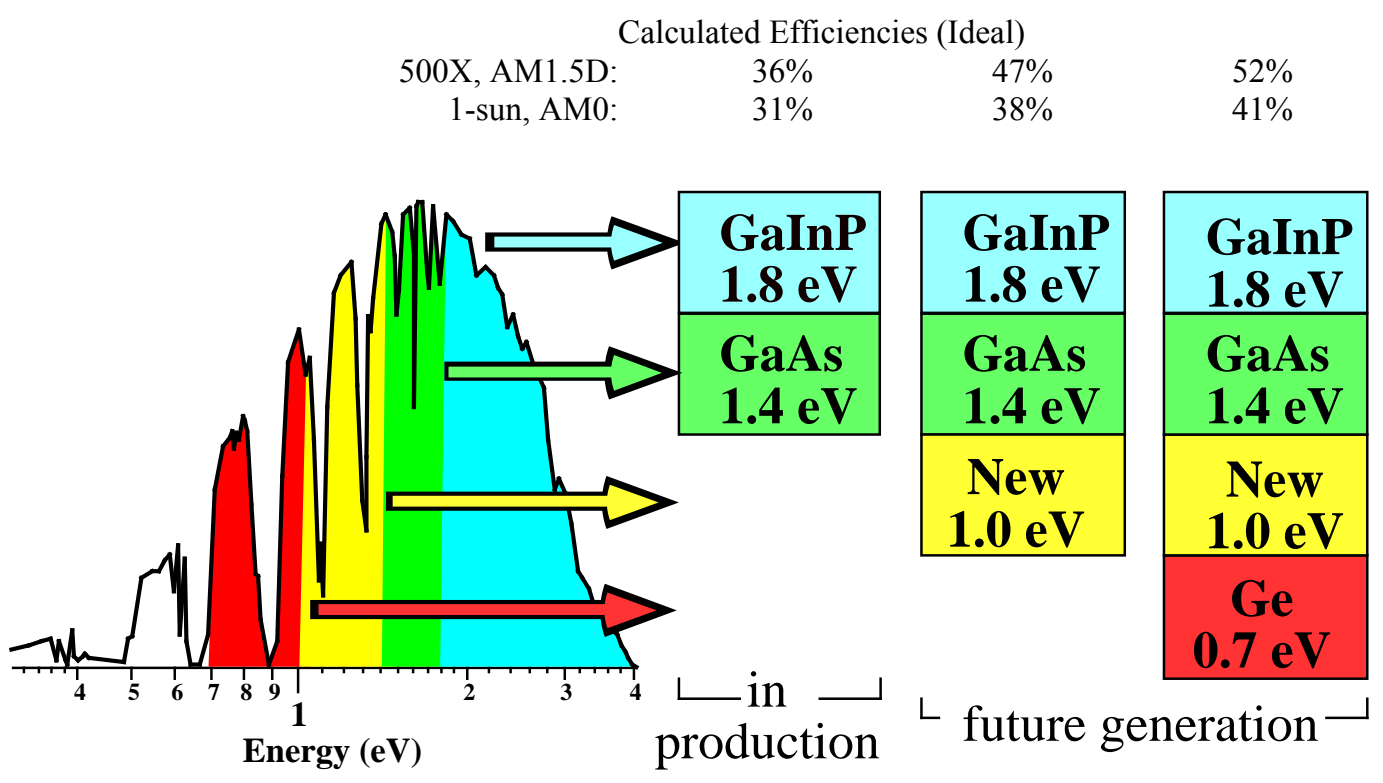

FIGURE 1. Multijunction solar cells use the solar spectrum more efficiently.

It has recently been shown that $\mathrm{N}$ induces a very large band-gap bowing for the $\mathrm{Ga}_{1-\mathrm{x}} \mathrm{In}_{\mathrm{x}} \mathrm{N}_{\mathrm{y}} \mathrm{As}_{1-\mathrm{y}}$ alloy system. Concentrations of $\mathrm{N}$ as low as a few percent lower the band gap by a significant fraction of an $\mathrm{eV}(4)$. Furthermore, with $\mathrm{y} \approx 0.35 \mathrm{x}$, the alloy is lattice-matched to GaAs (or Ge). We propose this material for a 1-eV GaAs-latticematched solar cell. We demonstrate several working prototype 1-eV solar cells based on GaInNAs active layers lattice-matched to GaAs that may be suitable for the third cell of the next generations of ultrahigh-efficiency devices, if problems with the quantum efficiency can be overcome.

\section{RESULTS AND DISCUSSION}

\section{Growth of GaInNAs}

We have grown epitaxial $\mathrm{Ga}_{1-\mathrm{x}} \mathrm{In}_{\mathrm{x}} \mathrm{N}_{\mathrm{y}} \mathrm{As}_{1-\mathrm{y}}$ by metal-organic vapor-phase epitaxy (MOVPE) on slightly misoriented (001) GaAs substrates using trimethylgallium (TMGa), trimethylindium (TMIn), arsine $\left(\mathrm{AsH}_{3}\right)$, and dimethylhydrazine (DMHy) as the nitrogen source. For GaInNAs layers grown without any intentionally introduced dopant, the resulting background doping is p-type on the order of $10^{17} \mathrm{~cm}^{-3}$, probably largely from carbon introduced into the as-grown material from the dimethylhydrazine. Si (from disilane) and Se (from hydrogen selenide) were used as n-type dopants, while $\mathrm{Zn}$ (from diethylzinc) and the background doping were used as a p-type dopants.

The nitrogen incorporation into GaInNAs is found to depend sensitively on the growth temperature and $\mathrm{DMHy} / \mathrm{AsH}_{3}$ flow ratio (5). For this reason, the GaInNAs layers were grown at relatively low temperatures of $580^{\circ}-650^{\circ} \mathrm{C}$ and high $\mathrm{DMHy} / \mathrm{AsH}_{3}$ flow ratios ranging from 8 to 110 . The compositions of the GaInNAs epilayers were 


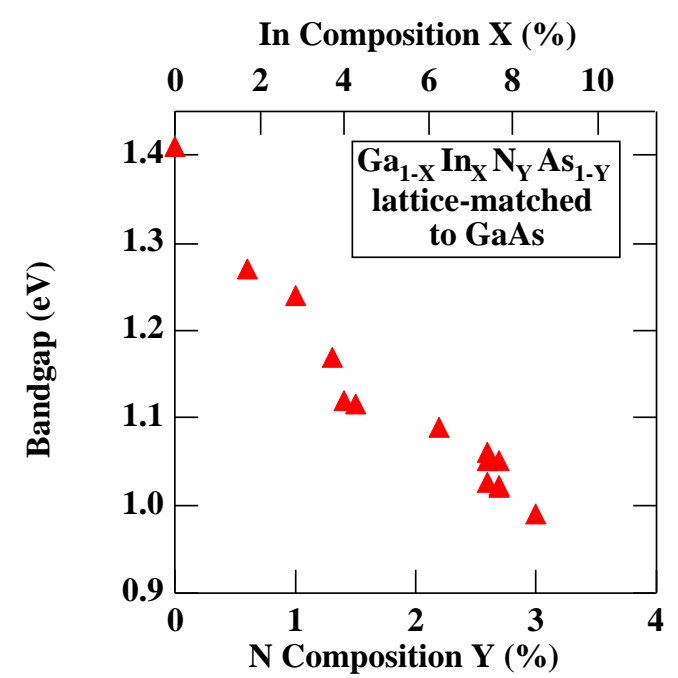

FIGURE 2. Band gap of $\mathrm{Ga}_{1-\mathrm{x}} \operatorname{In}_{\mathrm{x}} \mathrm{N}_{\mathrm{y}} \mathrm{As}_{1-\mathrm{y}}$ latticematched to GaAs.

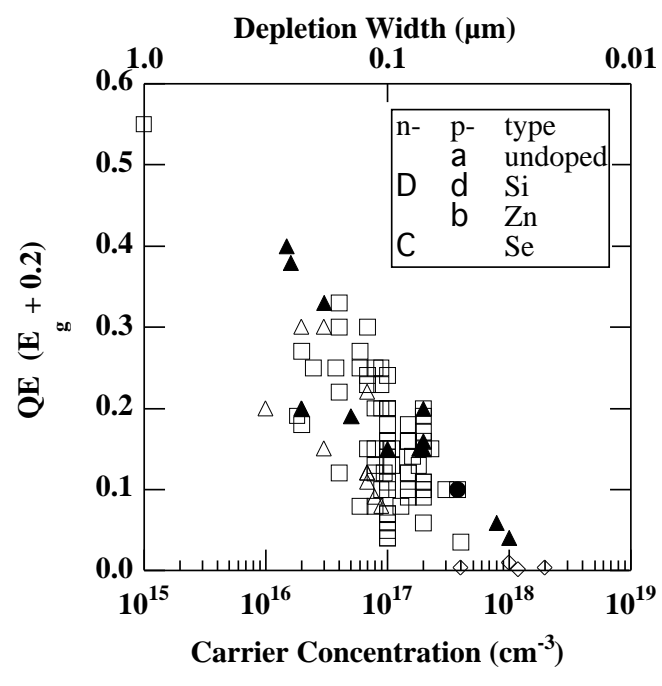

FIGURE 3. QE vs. carrier concentration and depletion width.

determined by X-ray diffraction measurements and selectively confirmed by secondaryion mass spectroscopy (6). The band gaps were determined from quantum efficiency (QE) spectra.

Figure 2 shows the band gap of $\mathrm{Ga}_{1-\mathrm{x}} \mathrm{In}_{\mathrm{x}} \mathrm{N}_{\mathrm{y}} \mathrm{As}_{1-\mathrm{y}}$ layers grown lattice-matched to GaAs. A continuous range of band gaps from $1.4 \mathrm{eV}$ (GaAs) down to $0.9 \mathrm{eV}$ have been produced in layers with good crystalline quality and specular morphology.

This material therefore holds great promise as a third junction in a multijunction III$\mathrm{V}$ solar cell because it can be grown lattice-matched to GaAs with a band gap of $1 \mathrm{eV}$. But a serious challenge remains to be met. We have shown that the minority-carrier diffusion lengths of the GaInNAs material grown to date are very short (6). The magnitude of the electrochemical QE for a large number of epilayers of GaInNAs are shown in Figure 3 to strongly correlate with the carrier concentration, and therefore, with the depletion width. This evidence indicates that the carrier collection observed is dominated by field-aided collection within the depletion width, rather than diffusion collection, which is more common to typical III-V semiconductors. Thus, the diffusion lengths in this GaInNAs material are shorter than the 0.04 to $0.4 \mu \mathrm{m}$ depletion widths and much shorter than typical GaAs or GaInP diffusion lengths. We will show in the following section how this property of the GaInNAs material affects the solar-cell device performance.

\section{1-eV GaInNAs solar-cell devices}

We have fabricated a number of device structures using p-on-n and n-on-p GaInNAs homojunction and GaAs/GaInNAs heterojunction structures (7,8). The structures consisted of a GaAs buffer layer, a $1 \mu \mathrm{m}$ thick GaInNAs base, a 0.1-0.2 $\mu \mathrm{m}$ thick GaAs or GaInNAs emitter layer, a thin GaInP window layer, and a highly doped GaAs contact 


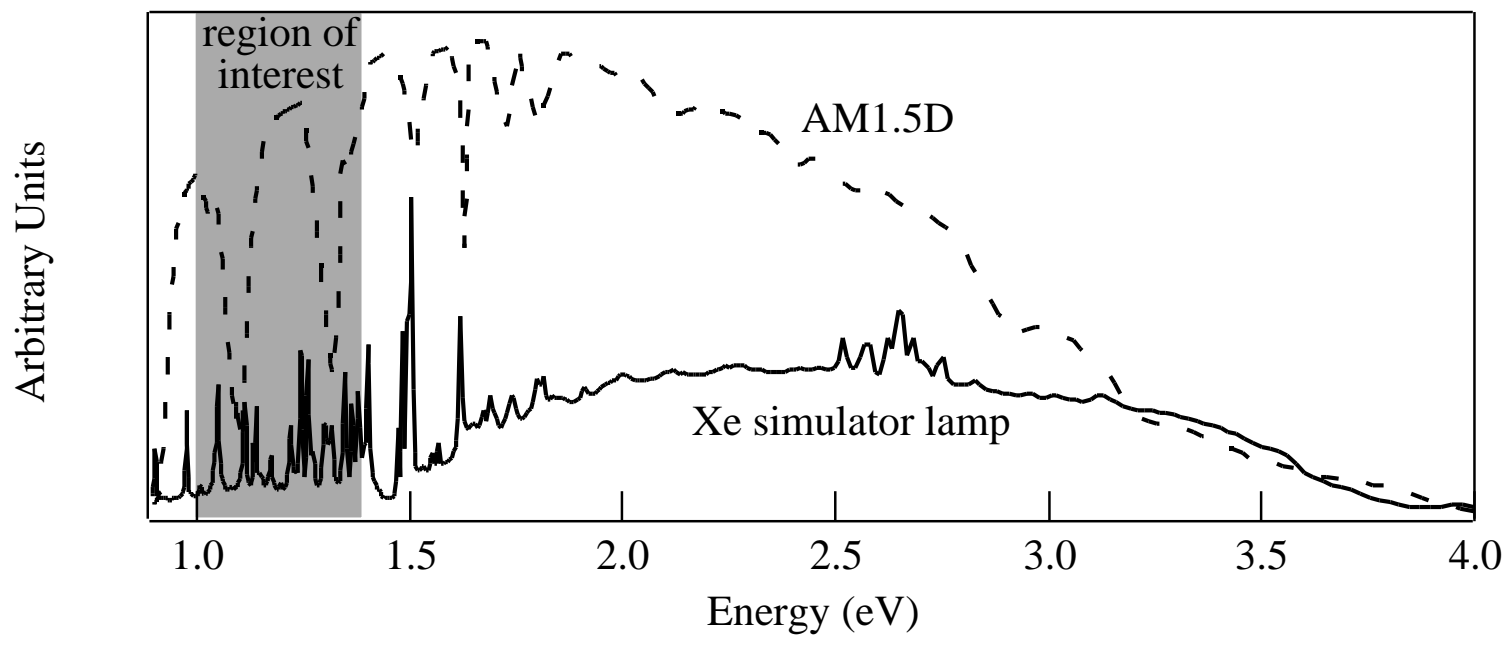

FIGURE 4. AM1.5 direct solar (dashed) and Xe simulator lamp (solid) spectra, with spectral region of interest for $1-\mathrm{eV}$ cells shown in gray.

layer. In some cases, a GaInP back-surface-field (BSF) was also included. The structures were processed into solar cells with electroplated Au front grids and back contacts, with etched mesas defining an illuminated area of $0.10 \mathrm{~cm}^{2}$. No antireflection coatings were applied.

The short-circuit current of these $1-\mathrm{eV}$ cells must be well characterized to currentmatch this junction to the other junctions within a multijunction solar cell device, but this characterization is not trivial. Because the cells are eventually intended to be incorporated as a third cell below GaAs, the spectral region of interest is between 1.0 $\mathrm{eV}$ and $1.4 \mathrm{eV}$. Figure 4 illustrates some of the difficulties in measuring such a cell. Within the narrow spectral region of interest, the terrestrial solar spectrum contains two strong water absorption bands, and the simulator's xenon-lamp spectrum contains multiple spikes. In addition, variations in the band gap of the GaInNAs alloy and drifts in the spectrum of the simulator can cause significant variation in the spectral correction factor. Therefore, the device currents were determined by integrating the measured external QEs of the devices against the ASTM standard AM1.5 direct spectrum (1000 $\mathrm{W} / \mathrm{m}^{2}$ ) over the energy range below the GaAs band gap. The devices were then placed in the solar simulator and covered by a GaAs filter to remove light above the GaAs band edge. The simulator intensity was adjusted to set the short-circuit current of the device being measured in the simulator equal to its AM1.5D current calculated as described above. The current-voltage (I-V) curves were then measured at this simulator intensity.

The short-circuit current density $\left(\mathrm{J}_{\mathrm{sc}}\right)$, open-circuit voltage $\left(\mathrm{V}_{\mathrm{oc}}\right)$, and fill factor $(\mathrm{FF})$ from these IV curves are summarized in Table 1, along with ideal values used to calculate the theoretical efficiencies of multijunction solar cells. The three different device structures with a high base doping $\left(10^{17} \mathrm{~cm}^{-3}\right)$ are very similar in performance. All of these $J_{\mathrm{sc}}$ are significantly lower than the $10 \mathrm{~mA} / \mathrm{cm}^{2}$ required in a multijunction solar cell due to low QEs of about 0.2. A significant increase in $\mathrm{J}_{\mathrm{sc}}$, though, was 
TABLE 1. GaAs-filtered AM1.5D device performance parameters without antireflection coat.

\begin{tabular}{cccccc}
\hline Device & $\begin{array}{c}\text { Base } \\
\text { Doping }\left(\mathrm{cm}^{-3}\right)\end{array}$ & BSF & $\begin{array}{c}\text { Jsc } \\
\left(\mathrm{mA} / \mathrm{cm}^{2}\right)\end{array}$ & $\begin{array}{c}\text { Voc } \\
(\mathrm{mV})\end{array}$ & $\begin{array}{c}\mathrm{FF} \\
(\%)\end{array}$ \\
\hline $\mathrm{n} / \mathrm{p}$ homojunction & $10^{17}$ & no & 1.8 & 435 & 64 \\
$\mathrm{n} / \mathrm{p}$ heterojunction & $10^{17}$ & no & 1.8 & 435 & 66 \\
$\mathrm{p} / \mathrm{n}$ homojunction & $10^{17}$ & no & 1.8 & 353 & 61 \\
$\mathrm{p} / \mathrm{n}$ homojunction & $10^{15}$ & yes & 7.4 & 281 & 53 \\
ideal & & & 10 & 625 & 84 \\
\hline
\end{tabular}

observed in the device with low base doping $\left(10^{15} \mathrm{~cm}^{-3}\right)$. As we discussed earlier, the short diffusion lengths in this GaInNAs material results in collection primarily within the depletion width. In the low-doped device, the depletion width is about 3-4 times larger than in the higher-doped devices, resulting in corresponding increases in the QE and $\mathrm{J}_{\mathrm{sc}}$. Comparisons of the QE spectra and I-V curves are shown in Figures 5 and 6 , respectively. It should be noted that the efficiency of the device is not proportionally enhanced, because the $\mathrm{V}_{\text {oc }}$ is diminished due to increased dark current. Although the improvement observed in device performance by using low base doping is still far from ideal, the $\mathrm{J}_{\mathrm{sc}}$ is approaching a value that would allow the incorporation of the cell into a multijunction device without significant current losses in the GaAs and GaInP junctions. Continued improvement of the structure along these lines could realistically result in a multijunction device with an increase in efficiency over the GaInP/GaAs tandem cell, but less than the theoretical efficiencies presented in Figure 1. This, though, may require a further reduction in the base doping. Achieving such a low doping density will not be easy, given the $10^{17} \mathrm{~cm}^{-3}$ p-type background doping; either a very delicate n-type counter-doping, a change in a growth condition (e.g., changing the nitrogen source), or a treatment such as annealing will be required to lower the background doping level.

To truly realize the projected efficiency boasts, the reason for the short diffusion lengths must be understood and fixed. We have made several attempts to increase the diffusion lengths by varying growth conditions, purifying the DMHy, and annealing samples; but, to date, the diffusion lengths appear to remain unaffected, though some changes of material quality have been seen through Hall mobility and photoluminescence intensity measurements (6). We are currently collaborating extensively with several other groups to understand the reason for these short diffusion lengths.

\section{CONCLUSION}

Ultra-high efficiencies have been predicted for multijunction III-V solar cells if a satisfactory third junction material can be identified. The GaInNAs alloy is a promising candidate because it has been grown lattice-matched to GaAs with a $1-\mathrm{eV}$ band gap. But device performance has been less than ideal due to short carrier diffusion lengths. Efforts to understand and eliminate the cause of the short diffusion lengths are ongoing. We have identified a depletion-width-enhanced device structure that may be able to be 


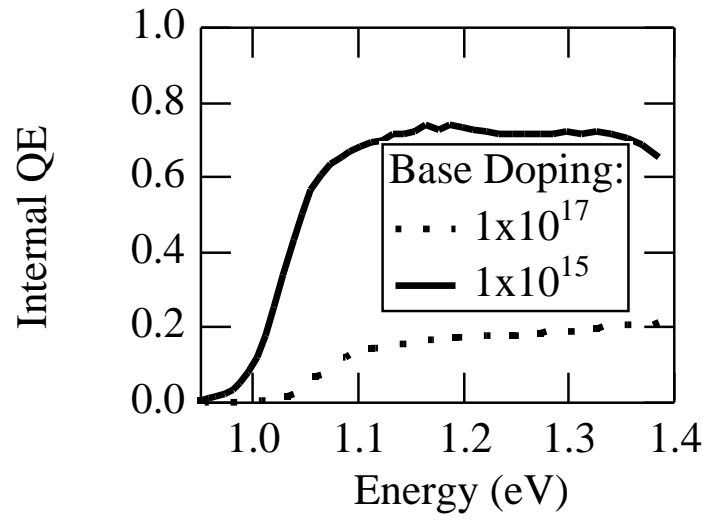

FIGURE 5. Internal QE spectra of two $\mathrm{p} / \mathrm{n}$ GaInNAs homojunction devices with base dopings of $10^{17} \mathrm{~cm}^{-3}$ (dashed) and $10^{15} \mathrm{~cm}^{-3}$ (solid).

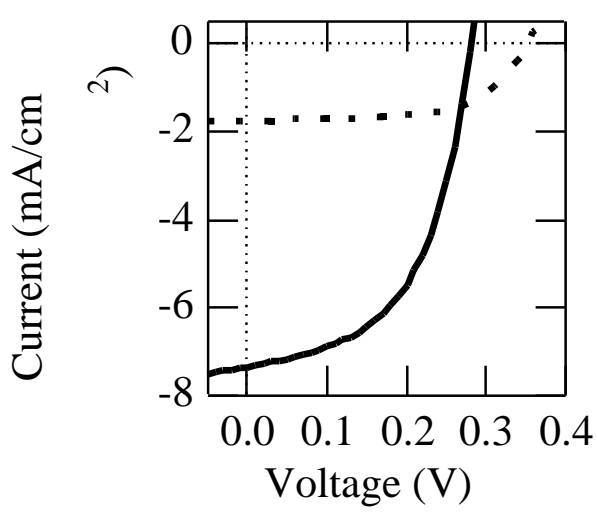

FIGURE 6. I-V curves of same devices shown in Figure 4. Base dopings are $10^{17} \mathrm{~cm}^{-3}$ (dashed) and $10^{15} \mathrm{~cm}^{-3}$ (solid).

current-matched to the existing GaInP/GaAs tandem cell, resulting in a slight increase in efficiency.

\section{ACKNOWLEDGEMENTS}

This work was supported by the U.S. Department of Energy under Contract Number DE-AC36-83CH10093.

\section{REFERENCES}

1. K. A. Bertness, S. R. Kurtz, D. J. Friedman, A. E. Kibbler, C. Kramer, and J. M. Olson, Appl. Phys. Lett. 65, 989 (1994).

2. T. Takamoto, E. Ikeda, H. Kurita, and M. Ohmori, Appl. Phys. Lett. 70, 381 (1997).

3. S. R. Kurtz, D. Myers, and J. M. Olson, in 26th IEEE Photovoltaic Specialists Conference (IEEE, New York, Anaheim), 1997, pp. 875-878.

4. M. Weyers, M. Sato, and H. Ando, Jpn. J. Appl. Phys. 31, 853 (1992).

5. M. Weyers and M. Sato, Appl. Phys. Lett 62, 1396 (1993).

6. J. F. Geisz, D. J. Friedman, J. M. Olson, S. R. Kurtz, and B. M. Keyes, J. Cryst. Growth 175, in press (1998).

7. D. J. Friedman, J. F. Geisz, S. R. Kurtz, and J. M. Olson, in 2nd World Conference on Photovoltaic Solar Energy Conversion (IEEE, Vienna), 1998, in press.

8. D. J. Friedman, J. F. Geisz, S. R. Kurtz, and J. M. Olson, J. Cryst. Growth 175, in press (1998). 